\title{
Analysis on College English Teaching Pattern under Intercultural Perspective
}

\author{
Han Gao \\ Huanghe Science and Technology College \\ Zhengzhou, China, 450000
}

\begin{abstract}
At present, domestic English teachers have set some intercultural teaching strategies to improve students' enthusiasm. This article mainly bases on students' positive emotion or attitude in learning English to explore intercultural English teaching pattern, in order to set teaching pattern by taking the promotion of students' learning enthusiasm as the objective. Stimulation is a kind of method to promote students' learning motivation. This research provides preliminary support for assumption of teaching pattern of the theme. Meanwhile, stimulating students' enthusiasm can reasonably deal with students' moodiness in learning. Although through stimulation or promotion, students can acquire high marks in English learning and improve their marks, it is the most important to provide students with more interest and opportunities to improve their ability.
\end{abstract}

Keywords-college English; teaching pattern; intercultural communication

\section{INTRODUCTION}

At the present stage, international communication and intercultural teaching pattern have been considered to be important criterions to promote English learning of college students. In today's globalization, English has become a global language. Meanwhile, it plays an important role in international politics, economy, culture, commerce and trade and information exchange. In international communication, English is of vital importance. The progress of science and technology information at present makes exchange of information in various countries in the world more convenient as well as expands and extends the internalization of future education. The English teaching for college students in China becomes more and more extensive. Non-English major students have the opportunity to participate in international communication and cultural communication on the basis of considering future career. In this way, the present intercultural teaching has typical positive significance on English teaching for college students.

\section{THEORETICAL BASES}

\section{A. Definition of Culture}

Culture is a very extensive concept. It is very difficult to give it a strict and accurate definition. Many philosophers, sociologists, anthropologists, historians and linguists always make efforts to define the concept of culture from the perspectives of their disciplines. However, so far, it hasn't got a recognized and satisfactory definition. Broadly speaking, culture is a kind of social phenomenon, the product formed by people in long-term creation, a kind of historical phenomenon and accumulation of social history. Properly speaking, culture congeals in substance and dissociate outside substance. It is state or national history, geography, local conditions and customs, traditional custom, way of life, literature and art, behavior standards, way of thinking and value that can be inherited. In addition, culture is also a kind of generally approved ideology that can be inherited for people to exchange. [1]

\section{B. Current Situation of Culture Teaching}

Because cultural factor plays an important role in English learning, culture learning has become an important element, which is inseparable from English learning. However, there exist some problems in English classroom teaching. The first is the misunderstanding of English learning. When we try to learn English, except for grammar, pronunciation and other elements, we shall also understand cultural background of country and people. Different languages have many different words, differences in pronunciation and thinking model. In order to correctly express our thoughts, we must understand culture of this country. If we only learn the meaning of foreign language, it is impossible for us to master this language. Culture can truly reflect the history, customs and traditions of a country. Therefore, if we can better master the culture of a country, we can better master the language.

Most of the Chinese learners think the main purpose of English learning is to "pass the exam". When they learn English, they often attach importance to mastering language knowledge and basic skill, such as vocabulary, listening, speaking, reading and writing, which are often tested in exams. Therefore, although some English learners may have already mastered the whole grammar system, large vocabulary and standard pronunciation, they find it is difficult to understand people who say native language and cannot speak English fluently. But they can find many mistakes if they slowly read or write. The lack of cultural knowledge and ignorance of cultural difference always lead to inappropriate expression.

Another wrong idea is "instrumentalism". [2] In quite a long period of time, people's idea on English learning is greatly influenced by instrumentalism. They think language is just a tool for people to communicate, exchange ideas and 
opinions. However, this kind of so-called tool is the content not exceeding expression. It is very easy for this narrow understanding to make English learners to pay more attention to the tool itself, namely the language itself, and ignore restriction of language element outside the language system, such as culture. Therefore, we must strengthen students' ability in thought and culture learning. Under this circumstance, language learners will learn second language culture under the influence of culture.

The second is inappropriate teaching methods and learning methods. In English class, cultural factor becomes a hot topic. Culture learning becomes important part of foreign language learning. Classroom teaching in language classroom teaching has been practiced for a long time. But at present, problems still exist in culture teaching and learning in English classroom teaching.

Nowadays, people have changed old concepts in English teaching. They have to learn meaning of words as well as cultural knowledge. Scholars have realized that people shall pay more attention to how to use English. It is very important to understand how culture guides, because it provides the essence to deeply understand culture, helps you to understand interpersonal relationship between students and teachers and lets you know the importance of a familiar cultural education place. Therefore, teachers must comprehensively understand diversification of school in nation, culture and stratum and train students' ability of comprehensive language and culture. Language teachers shall take cultural language as the specialist of target culture and local culture as far as possible, thus they will have dual understanding for local culture and target culture. So schools shall send language teachers to foreign countries at fixed period o let them acquire personal experience and foreign culture, deepen understanding for target culture, do their best to make students' spoken English sound like native English. Language and culture influence each other. It is necessary to explain the importance of culture in the process of language learning and teaching. Teaching objectives are to help students to process language. It includes many aspects of language, such as listening, speaking, reading and translating. Therefore, if students want to better understand the above aspects, they have to know about culture.

\section{STRATEGIES TO IMPROVE INTERCULTURAL TEACHING}

\section{A. Promote Teachers' Intercultural Knowledge}

In intercultural communication, they come from different cultural background. In order to effectively communicate, the cognitive and adaptation competence of language knowledge play a vital role in proper and accurate expression and successful communication to adapt to contextual factors and communicative purpose, including objective world, world of public relations and mental world. In the end, the application of language is the process to continuously choose language, no matter the choice is conscious or unconscious. Multicultural teachers shall have comprehensive perspectives of eastern culture and western culture, eliminate narrow national culture of selfish departmentalism, and understand multi-culture and cross-culture by using multicultural perspective. [3]
In face of diversified world pattern and development of human culture, teachers shall be impartial to cultural difference. When it is different from cultural value of foreign culture, they shall understand and deal with diversification of this kind of culture. Secondly, as spreader of culture, teachers shall promote cultural communication in a diversified and open way and respect identification between different cultures. Furthermore, teachers shall be local cultural workers and advocators to deepen students' understanding for Chinese culture and set up correct cultural values. With diversified development of the world, form of knowledge has become diversified. The value of local knowledge has got attention. [4] Intercultural education shall cultivate students' international consciousness. It is the understanding of foreign culture as well as native consciousness. Train their ability, in modern society, according to requirements of local society to accept the identification, make them become inheritors of local culture to analyze foreign culture. Teachers shall learn the culture of native language and understand native culture and foreign culture. In order to realize the value of local knowledge and local cognitive style that help students' physical and mental development and continuous development of society, they shall more sensitively feel the existence of local knowledge and pay more attention to protecting and developing the value of local knowledge.

As the communication subject of knowledge and methods, teachers shall establish student-centered education concept. In face of cultural inheritance, it is necessary to base on students' interests, needs and psychological characteristics, adjust their teaching strategies, reflect teaching, pay attention to academic trend of intercultural education, reflect and analyze problems existed in teaching and improve teaching strategies and activities. They can also refer to successful experience and excellent teachers, including several detailed steps. Firstly, change the experience of intercultural education into theoretical thinking that bases on experience; secondly, improve reflection level of English teachers; thirdly, develop teaching skills; finally, strengthen language competence of English teachers of intercultural education to lay foundation for direction of intercultural education.

\section{B. Update Students' Intercultural Communication Awareness}

How to make students understand cultural difference is the key to improve English teaching effect. In teaching process, in comparison of language and culture, teachers shall wisely regard cultural difference. On one hand, teachers can design some situations and plots in students' learning and life for them to experience cultural difference; on the other hand, teachers can encourage students to experience diversification of culture through reading books and magazines and practical communication. According to theory and methods of cultural linguistics, teachers can research multi-culture and use it in intercultural teaching. Teachers shall do their best to turn center of teaching from "teaching" to "learning". Therefore, teachers shouldn't only impart knowledge, nor introduce theme, scope and method of cultural research for students. They can define types and scopes of intercultural communication and help students to learn language through discourse expression and learning contents of culture. Teachers 
shall encourage students to treat ethnocentrism that is neither arrogant nor self-abased with cultural equality and language equality.

When researching culture, teachers shall overcome cultural bias, eliminate boundedness of their own from their values and review literature with scientific attitudes. In teaching, teachers shall provide more opportunities for students to face and solve problems and cultivate students' cultural strategies. Intercultural education shall run through the whole process of English teaching, which is the inheritance of cultural connotation. Teachers shall carry out reading, speaking, grammar and vocabulary teaching related to intercultural education in various ways. They can expand connotation and extend cultural education, look the whole English teaching as a kind of cultural education and integrate cultural education in English teaching steps and activities. It refers to the thought and way of thinking related to foreign culture to reflect traditional ideas and way of thinking of Chinese people. They can change some old educational thoughts and methods, change the roles of teachers and students as well as classroom teaching model to make teachers and students expand their way of thinking in English teaching and learning. The contents of cultural teaching in English teaching shall not be limited to culture of English-speaking countries. Intercultural awareness has very rich contents. It requires people to understand and think problems from global perspective. It includes sensitivity of culture in English-speaking countries and culture of nonEnglish-speaking countries. Therefore, students can learn culture of English-speaking countries. In the process of learning English, they can also take English as a tool to gain the whole world. Teachers shall help students to learn culture of English-speaking countries, use an open mind to encourage them to take English as the tool to form an international consciousness.

\section{Improve Quality of Intercultural Teaching Model}

The purpose of intercultural teaching is to improve students' ability to communicate with others by using language and ways in target society. Students must understand rich cultural connotation of vocabulary in target language, so that they can master rules of language application. Experience shows that compared with regular structure, it is more important to use language rule. Only correct pronunciation, intonation and grammar can guarantee effective communication.

Through intercultural teaching, students can understand how people observe the world and deal with things in target language culture; moreover, they shall understand how people use language to reflect their social thoughts, habits and behavior, then reach the goal that uses proper language as way of communication in target culture. Cultivation of intercultural communicative ability becomes the objective of English teaching in the new period. The determination of objective embodies further development of social function of English, conforms to development tendency in aspects such as world's politics, economy and culture. It is also the requirement for foreign language teaching to serve the society. Realizing new teaching objectives needs us to update foreign language teaching idea and reform foreign language teaching system.

\section{Application of Extracurricular Culture Teaching}

Extracurricular culture teaching is a kind of comprehensive teaching and needs the efforts of teachers and students. It shall seize key points of reading, writing, speaking and listening. As everyone can see, cultural factors and language influence each other. These factors will influence the language learning in listening, reading, writing and translation. First of all, students shall change wrong idea of English learning. The purpose of English learning is not only to acquire language skills, such as listening, reading, speaking and writing, but also to improve students' personality.

Colleges shall strengthen academic exercises and improve students' cultural personality, such as culture discussion and lectures. Holding cultural discussion under the guidance of teachers means all students carry out a series of discussion on cultural theme to seek ways to solve practical cultural problems and deepen understanding for this cultural theme. There are a lot of benefits to hold cultural discussion to cultivate students' personality.

Giving lectures on target culture or comparing Chinese culture and English culture is another effective way to improve students' cultural consciousness. Each speech centers on one topic, such as its history, geography or politics. Through a series of lectures, teachers can introduce category of English culture for students. They shall complete all these things systematically, which will help students to understand cultural characteristics of English-speaking countries and people.

In English learning and teaching, cultural factor is the most important as well as the most difficult point. It is also the most important problem. Some social scientists think it is the key to language. Language is the symbolic representation of a person, including their historical and cultural background and way of thinking. With the development of many countries, cultural teaching in language teaching receives extensive attention from linguists, education experts and foreign language teachers. They are seeking many methods to overcome problems from many aspects. We can learn culture through proverbs, folk stories, legends, mythology, art and media.

Many students complain that they have poor ability in foreign language listening and it is difficult for them to improve. Language learners need good language foundation, large vocabulary and grammar knowledge, as well as knowledge about cultural background. So it is necessary to understand cultural knowledge of language learnt by them. They often find that they are easy to understand the topic of listening that they are familiar with, but it is very different to understand subjects that they don't know. Reading comprehension is another factor to influence English learning. Through reading materials, we can understand information about religion, food, clothing, housing, toys or books. Therefore, everything experienced by a person is a part of his/her culture. In English, there are some phrases. For example, "green-eyed master" means someone envies others. But in China, people use "red eyes" to express the feeling to envy others. In Chinese, "back tea and brown sugar" use "red". But when translating it into English, we often use "black teach, brown sugar". [5] 
Through words, we can see people with different educational levels. Translation is not only to simply translate a language but also translate a kind of culture. So we can see the importance of cultural factors. Translation is the exchange between different cultures. Because of culture differences, we shall also pay attention to cultivation of communicative ability. Teachers must keep open dialogue with students. Teachers shall discuss learning style with students. It requires students to establish relationships between course content and primary method of learning. In this way, teachers and students can jointly realize mutual understanding and common telecommunication criterion. Teaching material is a good helper for students. Culture has penetrated in every corner of the society. So students shall collect resources from many aspects of life.

\section{CONCLUSION}

International development makes intercultural contact more frequent and universal. People have to convey new technology and information system. The rapid development of global economy shows the importance of culture. Therefore, the importance of cultural teaching and English learning does not take foreign language as instrumental goal. It makes for personality of English learners and plays an important role in cultivating students' social competence. Language learners shall learn language skills as well as culture, overcome cultural barrier and promote intercultural communication competence. The influence of language that has significant impact has on human behavior is always ignored. The ability of speaking and writing is regarded as natural thing. Language is an indispensable part of culture and influenced by culture.

Culture is important, because people have to use it, share it and express their ideas and emotion. Culture has relatively strong influence on communicative behavior. Because people around the world live in a society full of culture, besides, human and culture are extremely complicated, students shall understand knowledge related to nation and culture. Meanwhile, teachers shall teach informal cultural knowledge to let students understand how to treat each other, respect all other informal cultural rules to strengthen students' communicative ability. This article puts forward some intercultural teaching strategies for college English teaching to refer to, in order to effectively teach college English. The ultimate purpose of intercultural education is to let students have rich intercultural knowledge, train intercultural respectful, tolerant, equal and objective attitude, and let students have an open mind, form objective international consciousness and effectively apply English without being influenced by prejudice.

\section{REFERENCES}

[1] Chen Jia. Enlightenment of Interactive Mode Theory on Teaching of College English Reading [J], Journal of Shenyang Normal University, 2008, (2): 155-157.

[2] He Qinghua. Research on College English Acquisition under Network Environment [M], Kunming: Yunnan University Press, 2011:128-131.

[3] Shu Dingfang, Chen Suyan. The Road to Success of College English Teaching: Investigation on "Professional Orientation" of English
Teaching Pattern in the University of Nottingham in Ningbo [M], Shanghai: Shanghai Foreign Language Education Press, 2010:6, 118120.

[4] Wang Qin, Zuo Wei. Discussion on Cultivation of Metacognitive Strategy in College English Learning [J], Journal of Xichang College (social science edition), 2012 (1): 151-156.

[5] Zhuang Enping, editor-in-chief. Intercultural Foreign Language Teaching: Research and Practice [M], Shanghai: Shanghai Foreign Language Education Press, 2012, 12, 157-208. 